УДК 378.147

DOI https://doi.org/10.26661/2522-4360-2021-2-20

\title{
ЕКСПЕРИМЕНТАЛЬНА ПЕРЕВІРКА ЕФЕКТИВНОСТІ СФОРМОВАНОСТІ ДІЯЛЬНІСНОГО КОМПОНЕНТА ГОТОВНОСТІ МАЙБУТНІХ ФАХІВЦІВ ІЗ ФІЗИЧНОГО ВИХОВАННЯ І СПОРТУ ДО СПОРТИВНО-МАСОВОЇ ТА ФІЗКУЛЬТУРНО-ОЗДОРОВЧОЇ РОБОТИ
}

\author{
Долинний Ю. О. \\ кандидат педагогічних наук, доцент, \\ в. о. завідувача кафедри фізичного виховання $і$ спорту \\ Донбаська державна машинобудівна академія \\ вул. Академічна, 72, Краматорськ, Донецька область, Украӥна \\ orcid.org/0000-0002-5804-4941 \\ mr.dya69@gmail.com \\ Черненко С. О. \\ кандидат наук з фізичного виховання і спорту, доцент, \\ доцент кафедри фізичного виховання і спорту \\ Донбаська державна машинобудівна академія \\ вул. Академічна, 72, Краматорськ, Донеиька область, Україна \\ orcid.org/0000-0001-9375-4220 \\ mr.dya69@gmail.com \\ Олійник О. М. \\ старший викладач кафедри фізичного виховання і спорту \\ Донбаської державної машинобудівної академії \\ вул. Академічна, 72, Краматорськ, Донецька область, Украӥна \\ orcid.org/0000-0002-9197-1034 \\ mr.dya69@gmail.com
}

Ключові слова: експеримент, сформованість, діяльнісний компонент, фахівиі, фізичне виховання, спорт.
Актуальність дослідження зумовлена тим, що на стадії переходу від постіндустріального етапу суспільного розвитку до інформаційної епохи інтенсивність науково-технічного прогресу стала справжнім випробуванням для біологічних, адаптаційних, соціальних та інших аспектів буття сучасної людини. Сучасному соціуму вкрай потрібні висококваліфіковані, компетентні та конкурентоспроможні фахівці, здатні ефективно проводити спортивно-масові заходи, фізкультурнооздоровчу роботу, відновлювати стан здоров'я людей та молоді. Отже, якісна професійна підготовка здобувачів вищої освіти 3 фізичного виховання і спорту є актуальною проблемою сучасності.

Для експериментальної перевірки методики ефективності сформованості діяльнісного компонента готовності майбутніх фахівців із фізичного виховання і спорту до спортивно-масової та фізкультурно-оздоровчої роботи було запропоновано експертне оцінювання рівнів оволодіння професійною компетентністю майбутніх бакалаврів: проведено зіставлення розподілів здобувачів вищої освіти досліджуваних груп (порівнювалися відповідні розподіли на початку і в кінці формувального експерименту). Результати констатувального експерименту переконливо доводять необхідність суттєвої модернізації змісту освітньо-професійних програм підготовки бакалаврів із фізичного виховання і спорту, методів, форм, 
технологій формування готовності здобувачів вищої освіти до спортивно-масової та фізкультурно-оздоровчої роботи. Констатовано, що зміст навчального матеріалу, відображений у програмах навчальних дисциплін, підручниках, навчально-методичних посібниках, індивідуальних навчальних завданнях, недостатньо орієнтований на розвиток професійної компетентності здобувачів вищої освіти, їхніх потреб, мотивів, інтересів до спортивно-масової та фізкультурно-оздоровчої роботи.

\title{
EXPERIMENTAL VERIFICATION OF THE EFFICIENCY OF THE FORMATION OF THE ACTIVITY COMPONENT OF THE PREPAREDNESS OF FUTURE SPECIALISTS IN PHYSICAL EDUCATION AND SPORTS
}

\author{
Dolynniy Yu. O. \\ Candidate of Pedagogical Sciences, Associate Professor, \\ Acting Head at the Department of Physical Education and Sports \\ Donbas State Engineering Academy \\ Academic str., 72, Kramatorsk, Donetsk region, Ukraine \\ orcid.org/0000-0002-5804-4941 \\ mr.dya69@gmail.com \\ Chernenko S. O. \\ Candidate of Sciences of Physical Education and Sports, Associate Professor, \\ Associate Professor at the Department of Physical Education and Sports \\ Donbas State Engineering Academy \\ Academic str., 72, Kramatorsk, Donetsk region, Ukraine \\ orcid.org/0000-0001-9375-4220 \\ mr.dya69@gmail.com \\ Oliynyk O. M. \\ Senior Lecturer at the Department of Physical Education and Sports \\ Donbas State Engineering Academy \\ Academic str., 72, Kramatorsk, Donetsk region, Ukraine \\ orcid.org/0000-0002-9197-1034 \\ mr.dya69@gmail.com
}

Key words: experiment, formation, activity component, specialists, physical education, sports
The relevance of the study is due to the fact that at the stage of transition from the post-industrial stage of social development to the information age, the intensity of scientific and technological progress has become a real test for biological, adaptive, social and other aspects of modern human existence. Modern society desperately needs highly qualified, competent and competitive specialists who are able to effectively conduct sports events, physical culture and health work, to restore the health of people and youth. Thus, high-quality professional training of higher education students in physical education and sports is an urgent problem of our time.

To experimentally test the methodology of the effectiveness of the formation of the activity component of the readiness of future specialists in physical education and sports for sports and mass and physical culture and health work, an expert assessment of the levels of professional competence of future bachelors was proposed: a comparison of the distributions of applicants for higher education of the studied groups (compared the corresponding distributions at the beginning and end of the formative experiment).

The results of the observational experiment convincingly prove the need for significant modernization of the content of educational and professional 
programs for bachelors in physical education and sports, methods, forms, technologies of forming the readiness of higher education students for sports and sports. It is stated: the content of educational material, reflected in the programs of academic disciplines, textbooks, teaching aids, individual educational tasks is not sufficiently oriented for the development of professional competence of applicants for higher education, their needs, motives, interests in sports and mass and physical culture and health work

Постановка проблеми. Демократичний розвиток суспільства, соціальна політика України потребує переходу до нового типу гуманістично-інноваційної фізкультурної освіти, що має здійснюватися на основі впровадження нового змісту, форм, методів навчання, підвищення якості професійної підготовки, розвитку професійно значущих якостей майбутнього фахівця 3 фізичного виховання і спорту, що взагалі відповідає вимогам сучасної професійної освіти у закладах вищої освіти [1].

Актуальність дослідження зумовлена тим, що на стадії переходу від постіндустріального етапу суспільного розвитку до інформаційної епохи інтенсивність науково-технічного прогресу стала справжнім випробуванням для біологічних, адаптаційних, соціальних та інших аспектів буття сучасної людини. Сучасному соціуму вкрай потрібні висококваліфіковані, компетентні та конкурентоспроможні фахівці, здатні ефективно проводити спортивно-масові заходи, фізкультурно-оздоровчу роботу, відновлювати стан здоров'я людей та молоді. Отже, якісна професійна підготовка здобувачів вищої освіти з фізичного виховання і спорту є актуальною проблемою сучасності [2; 3].

Аналіз останніх досліджень і публікацій. Теоретичний аналіз наукових джерел уможливив узагальнення значного досвіду теорії та практики професійної підготовки майбутніх фахівців із фізичного виховання і спорту у вищій школі, зокрема таких аспектів: професійної підготовки здобувачів вищої освіти (Ю. Бойчук, О. Дубасенюк, М. Євтух, В. Наумчук, В. Ягупов й інші); професійної підготовки здобувачів вищої освіти з фізичного виховання i спорту (Т. Бугеря, Л. Волошко, А. Герцик, М. Дутчак, Р. Карпюк, Т. Круцевич, Р. Клопов, А. Конох, О. Куц, М. Носко, В. Платонов, Є. Приступа, Л. Сущенко, О. Тимошенко, Б. Шиян, Ю. Шкребтій та інші); реалізації принципу неперервності професійної підготовки здобувачів вищої освіти з фізичного виховання і спорту (С. Гончаренко, І. Зязюн, С. Сисоєва, В. Кукса, Л. Сущенко).

Мета статті - екпериментально перевірити ефективність сформованості діяльнісного компонента готовності майбутніх фахівців із фізичного виховання і спорту до спортивно-масової та фізкультурно-оздоровчої роботи.

Виклад основного матеріалу дослідження. Для експериментальної перевірки методики ефективності сформованості діяльнісного компонента готовності майбутніх фахівців із фізичного виховання і спорту до спортивно-масової та фізкуль- турно-оздоровчої роботи було запропоновано експертне оцінювання рівнів оволодіння професійною компетентністю діяльнісного компонента готовності майбутніх здобувачів вищої освіти: проведено зіставлення розподілів здобувачів вищої освіти досліджуваних груп (порівнювалися відповідні розподіли на початку і в кінці формувального експерименту). А саме [4; 5]:

- емпіричні розподіли здобувачів вищої освіти експериментальних і контрольних груп за рівнями оволодіння діяльнісним компонентом готовності майбутніх бакалаврів із фізичного виховання і спорту до спортивно-масової та фізкультурнооздоровчої роботи при проміжному зрізі не відрізняються між собою $\left(\boldsymbol{H}_{0}\right)$;

- емпіричні розподіли здобувачів вищої освіти експериментальних і контрольних груп за рівнями оволодіння діяльнісним компонентом готовності майбутніх бакалаврів із фізичного виховання i спорту до спортивно-масової та фізкультурнооздоровчої роботи при проміжному зрізі відрізняються між собою $\left(\boldsymbol{H}_{\boldsymbol{1}}\right)$.

Розрахунки емпіричного значення статистичного критерію здійснювалися за допомогою комп’ютерної програми «Статистика в педагогіці» (в автоматичному режимі комп'ютерна програма вибрала статистичний критерій Пірсона $\chi^{2}$ ). Матриці зіставлення розподілів експериментальних і контрольних груп за сформованістю діяльнісного компонента готовності майбутніх здобувачів iз фізичного виховання і спорту до спортивно-масової та фізкультурно-оздоровчої роботи.

Про достовірність збігання (чи відмінностей) характеристик контрольних i експериментальних груп свідчать дані на перетині рядка і стовпчика матриці. Якщо критичне значення критерію $\chi^{2}$ більше за емпіричне, вибірки збігаються; навпаки, якщо критичне значення прийнятого критерію менше за емпіричне $\left(\chi_{\text {eмn }}^{2}>\chi_{\kappa p}^{2}\right)$, то, відповідно до статистичних правил прийняття рішення, гіпотеза $\boldsymbol{H}_{\boldsymbol{0}}$ відхиляється.

Причому, як це пораховано комп'ютерною програмою, характеристики вибірок збігаються на рівні значущості $\mathrm{p}=0,05$, а достовірність відмінностей характеристик вибірок становить 95\%.

Вдамося до аналізу результатів оволодіння професійною компетентністю діяльнісного компонента навчання майбутніх бакалаврів із фізичного виховання і спорту до спортивно-масової та фізкультурно-оздоровчої роботи при проміжному зрізі.

Дані сформованості діяльнісного компонента готовності майбутніх фахівців із фізичного 
виховання і спорту свідчать про певні зрушення у рівнях сформованості діяльнісного компонента готовності, уміння виконувати цей вид робіт за професійним напрямом роботи перевищують ці показники у здобувачів вищої освіти експериментальних груп (рис. 1).

Зокрема, під час проміжних замірів констатовано, що на 4,3\% зросла частка здобувачів вищої освіти експериментальних груп, які демонстрували високі рівні сформованості діяльнісного компонента готовності до професійної діяльності. У контрольних групах спостерігаються менш помітні зміни: на $0,5 \%$ зросла частка здобувачів вищої освіти, рівень сформованості діяльнісного компонента готовності яких експерти визнали високим. I навпаки, зменшилася частка здобувачів вищої освіти експериментальних груп на 6,4\%, 3 низьким рівнем сформованості діяльнісного компонента досліджуваної інтегративної властивості. Примітно, що в контрольних групах ця категорія здобувачів вищої освіти майже не змінилася.
Після завершення формувального експерименту за щойно виписаною методикою було проведено експертне оцінювання рівнів оволодіння професійною компетентністю діяльнісного компонента готовності майбутніх бакалаврів із фізичного виховання i спорту до спортивно-масової та фізкультурнооздоровчої роботи. Засобами комп'ютерної програми «Статистика в педагогіці» результати оцінювання готовності здобувачів вищої освіти контрольних та експериментальних груп до такого виду спортивно-масової та фізкультурно-оздоровчої роботи порівнювалися між собою, а також із відповідними результатами на початку формувального експерименту, здійснювалася оцінка динаміки формування компонентів цієї інтегративної властивості особистості та досліджуваного феномену загалом [6; 7].

Позитивні зрушення у рівнях оволодіння професійною компетентністю здобувачів вищої освіти до спортивно-масової та фізкультурно-оздоровчої роботи за визначеними критеріями та показниками зафіксовано у здобувачів вищої освіти як експериментальних, так і контрольних груп (табл. 1).

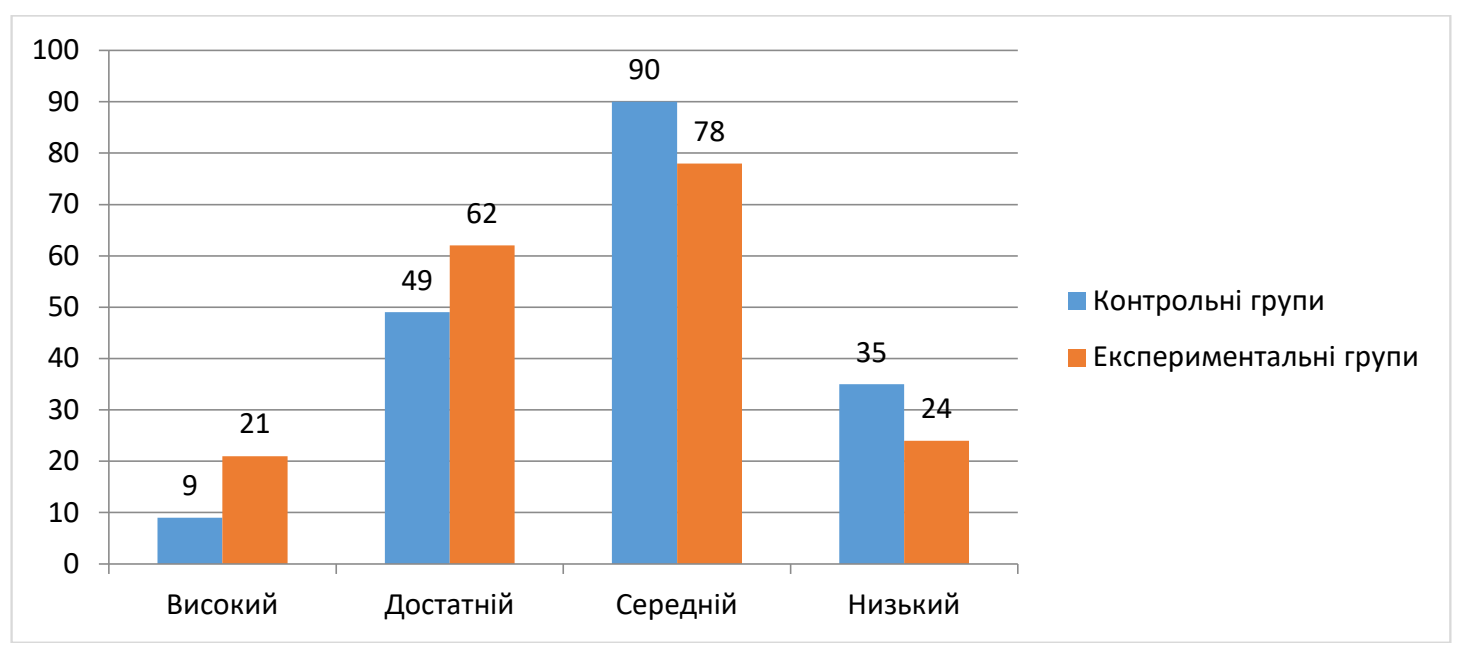

Рис. 1. Діаграма результатів експертного оцінювання сформованості діяльнісного компонента готовності майбутніх бакалаврів із фізичного виховання і спорту до спортивно-масової та фізкультурно-оздоровчої роботи (проміжний зріз)

Таблиця 1

Результати експертного оцінювання рівнів оволодіння професійною компетентністю здобувачів вищої освіти до спортивно-масової та фізкультурно-оздоровчої роботи (станом на завершення експерименту)

\begin{tabular}{|c|c|c|c|c|}
\hline \multirow[b]{3}{*}{ Рівні } & \multicolumn{2}{|c|}{ Контрольні групи } & \multicolumn{2}{|c|}{ Експериментальні групи } \\
\hline & $\begin{array}{c}\text { На початку } \\
\text { експерименту }\end{array}$ & У кінці експерименту & $\begin{array}{c}\text { На початку } \\
\text { експерименту }\end{array}$ & $\begin{array}{c}\text { У кінці } \\
\text { експерименту }\end{array}$ \\
\hline & $\begin{array}{c}\text { Відношення до } \\
\text { загальної кількості } \\
\text { здобувачів вищої } \\
\text { освіти, \% }\end{array}$ & $\begin{array}{c}\text { Відношення до } \\
\text { загальної кількості } \\
\text { здобувачів вищої } \\
\text { освіти, \% }\end{array}$ & $\begin{array}{c}\text { Відношення до } \\
\text { загальної кількості } \\
\text { здобувачів вищої } \\
\text { освіти, \% }\end{array}$ & $\begin{array}{c}\text { Відношення до } \\
\text { загальної кількості } \\
\text { здобувачів вищої } \\
\text { освіти, \% }\end{array}$ \\
\hline Високий & 4,3 & 6,6 & 3,8 & 16,4 \\
\hline Достатній & 25,0 & 29,7 & 24,2 & 42,0 \\
\hline Середній & 49,5 & 48,9 & 50,5 & 33,9 \\
\hline Низький & 21,2 & 14,8 & 21,5 & 7,7 \\
\hline Всього & \multicolumn{4}{|c|}{100} \\
\hline
\end{tabular}


Використовуючи результати тестування, анкетування, бесід, спостереження за підготовкою здобувачів вищої освіти до спортивно-масової та фізкультурно-оздоровчої роботи, результати виконання майбутніми бакалаврами 3 фізичного виховання i спорту проектів, практичних робіт, аналізуючи звіти респондентів з ознайомчої і виробничої практики, експерти констатували, що є суттєві позитивні зрушення у рівнях сформованості діяльнісного компонента готовності здобувачів вищої освіти до спортивно-масової та фізкультурно-оздоровчої роботи. Зокрема, на $30,4 \%$ зросла частка здобувачів вищої освіти експериментального масиву, сформованість діяльнісного компонента яких експерти визнали на високому і достатньому рівнях. I лише 14 здобувачів вищої освіти $(7,7 \%)$ експерти оцінили як таких, яким притаманний низький рівень сформованості умінь спортивно-масової та фізкультурно-оздоровчої роботи.

Крім кількісного, було проведено і якісний аналіз результатів формувального експерименту, який засвідчив динамічні позитивні зміни всіх показників сформованості діяльнісного компонента готовності майбутніх бакалаврів із фізичного виховання і спорту до спортивно-масової та фізкультурно-оздоровчої роботи. Здобувачі експериментальних груп демонстрували високі і достатні рівні діяльнісної сформованості професійної компетентності здобувачів вищої освіти з фізичного виховання i спорту під час навчання в закладах вищої освіти (уміння безпечно та ефективно використовувати спортивний інвентар для проведення спортивно-масових заходів; здатність ефективно реалізовувати фізкультурно-оздоровчу роботу, аналізувати та розв'язувати професійні конфлікти; вміння взаємодіяти 3 аудиторією, адаптуватися у різноманітних професійно-педагогічних ситуаціях; уміння використовувати фізкультурно-оздоровчі та тренувальні технології під час проходження виробничої практики, а згодом у майбутній професійній роботі.

Висновки і перспективи подальших досліджень у цьому напрямі. Програма педагогічного експерименту передбачала системно-послідовне виконання завдань дослідження у перебігу трьох етапів: діагностичного (планування експерименту, розроблення методики вимірювання показників, відбір контрольного та експериментального масивів, аналіз однорідності вибірок); технологічного (проведення констатувального та формувального експериментів); порівняльного (кількісний і якісний аналіз результатів констатувального та формувального експериментів, визначення достовірності результатів та обгрунтування висновків про педагогічний ефект).

Результати констатувального експерименту переконливо доводять необхідність суттєвої модернізації змісту освітньо-професійних програм підготовки бакалаврів із фізичного виховання і спорту, методів, форм, технологій формування готовності здобувачів вищої освіти до спортивно-масової та фізкультурно-оздоровчої роботи. Констатовано, що зміст навчального матеріалу, відображений у програмах навчальних дисциплін, підручниках, навчально-методичних посібниках, індивідуальних навчальних завданнях, недостатньо орієнтований на розвиток професійної компетентності діяльнісного компонента здобувачів вищої освіти, їхніх потреб, мотивів, інтересів до спортивно-масової та фізкультурно-оздоровчої роботи.

Наведені висновки підтверджуються результатами самооцінки студентами-випускниками власної підготовленості до спортивно-масової та фізкультурно-оздоровчої роботи. Зокрема, респонденти вказали, що недостатньо володіють уміннями і навичками (діяльнісний компонент готовності) здійснювати спортивно-масову та фізкультурно-оздоровчу діяльність із цією категорією людей: на цей факт вказали $39,4 \%$ опитаних.

Експериментальна перевірка ефективності сформованості діяльнісного компонента готовності майбутніх фахівців із фізичного виховання i спорту до спортивно-масової та фізкультурно-оздоровчої роботи засвідчила, що відбулися значні зміни діяльнісного компонента готовності до спортивно-масової та фізкультурно-оздоровчої роботи здобувачів вищої освіти контрольних груп.

\section{ЛIТЕРАТУРА}

1. Долинний Ю. Реалізація системи професійної підготовки майбутніх фахівців з фізичного виховання і спорту до реабілітаційної роботи з дітьми з обмеженими фізичними можливостями. Випуск 166. Серія: Педагогічні науки. Кропивницький: РВВ ЦДПУ ім. В. Винниченка. 2018. С. 80-85.

2. Долинний Ю. Професійна підготовка майбутніх фахівців з фізичного виховання і спорту. Взаємодія духовного й фізичного виховання в становленні гармонійно розвиненої особистості [Електронне видання]: збірник статей за матеріалами VI Міжнародної науково-практичної онлайн-конференції. Слов'янськ, 2019. С. 391-395.

3. Долинний Ю.О. Підготовка фахівців з фізичного виховання й спорту до професійної діяльності. Інноваційна педагогіка. Київ: Видавничий дім «Гельветика» 2020. «Причорноморський науководослідний інститут економіки та інновацій». Випуск 21, том. 1. м. Херсон, 2020. С. 203-207.

4. Сидоренко В.К. Основи наукових досліджень: навч. посіб. / В.К. Сидоренко, П.В. Дмитренко. Київ: РННЦ “ДІНІТ”, 2000. 259 с. 
5. Лузан П.Г. Основи науково-педагогічних досліджень: навчальний посібник / П.Г. Лузан, І.В. Сопівник, С.В. Виговська. Київ: ДАКККіМ, 2012. 368 с.

6. Рябова, 3.В. Моніторинг розвитку навчальної діяльності учнів загальноосвітнього навчального закладу: Науково - методичний посібник. Харків: Гімназія, 2004. - 72 с.

7. Лукіна, Т. Моніторинг якості освіти: теорія і практика. К.: Вид. дім «Шкіл. світ»: Вид. Л. Галіцина, 2006. $128 \mathrm{c}$.

\section{REFERENCES}

1. Dolynnyi Yu.O. (2018) Realizatsiia systemy profesiinoi pidhotovky maibutnikh fakhivtsiv z fizychnoho vykhovannia i sportu do reabilitatsiinoi roboty z ditmy z obmezhenymy fizychnymy mozhlyvostiamy. Red.kol.: V.F. Cherkasov, V.V. Radul, N.S. Savchenko ta in.. Vypusk 166. Seriia: Pedahohichni nauky. Kropyvnytskyi: RVV TsDPU im. V. Vynnychenka, pp. 80-85.

2. Dolynnyi Yu.O., Teslenko A.O. (2019) Profesiina pidhotovka maibutnikh fakhivtsiv z fizychnoho vykhovannia i sportu. Vzaiemodiia dukhovnoho y fizychnoho vykhovannia v stanovlenni harmoniino rozvynenoi osobystosti [Elektronne vydannia]: zbirnyk statei za materialamy VI Mizhnarodnoi naukovopraktychnoi onlain-konferentsii / hol. red. V.M. Prystynskyi. Sloviansk. pp. 391-395.

3. Dolynnyi Yu.O. (2020) Pidhotovka fakhivtsiv z fizychnoho vykhovannia y sportu do profesiinoi diialnosti. Naukovyi zhurnal «Innovatsiina pedahohika» zareiestrovano Ministerstvom yustytsii Ukrainy. Kyiv: Vydavnychyi dim «Helvetyka» 2020. «Prychornomorskyi naukovo-doslidnyi instytut ekonomiky ta innovatsii». Vypusk 21, tom. 1. m. Kherson. pp. 203-207.

4. Sydorenko V.K., Dmytrenko P.V. (2000) Osnovy naukovykh doslidzhen: navch. posib. K.: RNNTs "DINIT". (in Ukrajina)

5. Luzan P.H., Sopivnyk, S.V., Vyhovska I.V.(2012) Osnovynaukovo-pedahohichnykh doslidzhen: navchalnyi posibnyk. K.: DAKKKiM. (in Ukrajina)

6. Riabova, Z.V. (2004) Monitorynh rozvytku navchalnoi diialnosti uchniv zahalnoosvitnoho navchalnoho zakladu: Naukovo - metodychnyi posibnyk. Kh.: Himnaziia. (in Ukrajina)

7. Lukina, T. (2006) Monitorynh yakosti osvity: teoriia i praktyka. K.: Vyd. dim „Shkil. svit”: Vyd. L. (in Ukrajina) 